\title{
Dossiê: Livro Didático e Ensino de História
}

\author{
Luciana Rossato* \\ Vanderlei Machado**
}

O número 1 do volume 23 da Revista Cadernos do Aplicação aborda o livro didático de História. Busca situar sua historicidade, seus limites e possibilidades, além de apontar para a importância de novas pesquisas nesse campo. Livros didáticos são utilizados nas escolas brasileiras desde o século XIX. No início do século $\mathrm{XX}$, esses manuais correspondiam a dois terços dos livros publicados no país. Em 1996 representavam 61\% da produção nacional, segundo dados da Câmara Brasileira do Livro. Neste alvorecer do século XXI é possível afirmar que o livro didático de História está presente na maioria das escolas brasileiras. Essa presença crescente deve-se, principalmente, às políticas de distribuição empreendidas pelo Ministério da Educação, notadamente a partir de 1997. Destaca-se ainda o fato de que em 2008, pela primeira vez, alunos do Ensino Médio, das escolas públicas brasileiras, receberam gratuitamente livros didáticos de História. Com o Programa Nacional do Livro Didático (PNLD), o Brasil desenvolve o maior programa mundial de distribuição gratuita de livros didáticos para alunos das escolas públicas.

As pesquisas sobre os livros didáticos, com diferentes abordagens, tem sido crescente nos últimos trinta anos. Em 2009, durante o Encontro Nacional de História, realizado pela ANPUH (Associação Nacional de História), na cidade de Fortaleza, Ceará, foi apresentado um número considerável de pesquisas tematizando tanto o ensino de História quanto os livros didáticos. Alguns trabalhos demonstraram que esse instrumento pedagógico

* Doutora em História pela UFRGS e professora da Universidade do Estado de Santa Catarina. E-mail: lucianarossato@yahoo.com.br

** Doutor em História pela UFRGS e professor do Colégio de Aplicação da UFRGS. E-mail: vandermachado@hotmail.com 
continua sendo a principal fonte de aprendizagem para os alunos, bem como material de apoio para o professor em suas aulas (MOREIRA; CORTEZ, 2009). A fim de contribuir para qualificar e proporcionar uma melhor utilização do livro didático em sala de aula, muitos pesquisadores têm buscado analisar os usos que os professores e os alunos têm feito dos mesmos. Os livros identificados como didáticos possuem características particulares: de conteúdo, de linguagem, de forma, de autoria, de público alvo e de espaço de circulação. Das primeiras lições produzidas no século XIX para os alunos do Colégio D. Pedro II, passando pelos Compêndios até os atuais livros didáticos houve muitas mudanças. Formato e diagramação diferentes, conteúdo distinto, mas a mudança maior deu-se na importância e na centralidade que esse material passou a ocupar no processo ensinoaprendizagem. (GATTI Jr., 2004, p. 12)

Segundo Alain Choppin (2004) esse material pode exercer quatro funções essenciais. A função referencial (curricular ou programática) ao se constituir no suporte dos conteúdos e depositário dos conhecimentos, técnicas ou habilidades que um grupo social acredita que seja necessário transmitir às novas gerações”; a função instrumental ao sugerir métodos de aprendizagem e exercícios a fim de propiciar a aquisição de competências e habilidades; a função ideológica e cultural, que segundo o autor é a mais antiga, uma vez que o livro didático é "[...] um dos vetores essenciais da língua, da cultura e dos valores das classes dirigentes”, sendo reconhecido como "[...] um instrumento privilegiado de construção de identidade"; e a função documental, que surgiu muito recentemente, na qual acredita-se que o livro didático pode fornecer "[...] um conjunto de documentos, textuais ou icônicos, cuja observação ou confrontação podem vir a desenvolver o espírito crítico do aluno". (CHOPPIN, 2004, p. 553)

O dossiê Livro Didático e o Ensino de História reúne um conjunto de artigos escritos por pesquisadores que têm se dedicado à análise dos livros didáticos. O primeiro artigo "Ensino de História, um campo de pesquisa: reflexões sobre os livros 
didáticos" discute as principais diretrizes e tendências que têm influenciado as análises sobre este material nas últimas décadas, bem como as funções deste objeto cultural denominado livro didático. $\mathrm{O}$ artigo "Livro didático e memória - a construção do saber escolar sobre a História de Santa Catarina, nas primeiras décadas do século XX" dedica-se à análise do processo de construção das memórias sobre os heróis e mitos catarinenses na primeira metade do século XX, através dos livros didáticos produzidos neste período. Além disso, as autoras discutem as relaçóes estabelecidas entre a produção historiográfica e as apropriações para a construção de um conhecimento histórico escolar.

$\mathrm{O}$ terceiro e o quarto artigos analisam como determinados temas são tratados em diferentes livros didáticos. No artigo "O estudo da Idade Média em livros didáticos e suas implicaçôes no Ensino de História", o foco voltou-se para perceber como o conceito de Idade Média e temas do mundo medieval são apresentados em um conjunto de livros didáticos. Além disso, a autora, a partir de uma pesquisa com estudantes, propõe-se a analisar como os jovens se apropriaram desses saberes durante sua formação escolar básica. No artigo "Discursos sobre o islã e os muçulmanos em livros didáticos", são discutidos quais os elementos mais recorrentes nas narrativas sobre o islã e os muçulmanos em diferentes livros didáticos utilizados no Ensino Médio. A partir dos estudos interculturais, o autor pretende contribuir para que esse grupo seja visto em toda sua riqueza e pluralidade.

$\mathrm{O}$ artigo "Entre a legislação e a realidade das salas de aula: uma análise das políticas educacionais voltadas ao livro didático durante a Ditadura Civil-militar no Brasil a partir do relato de educadores" traz uma importante discussão sobre as políticas educacionais referentes ao livro didático elaboradas entre os anos de 1964 e 1974. Através de entrevistas, a autora analisa como esse material era utilizado pelos professores na época e sua influência na prática pedagógica deles. $\mathrm{O}$ sexto e último artigo deste dossiê, "A história recente nos livros didáticos: a ditadura militar e a questão da anistia no Brasil", discute maneiras de 
inserir a História recente do Brasil nas aulas do Ensino Médio ao investigar o tratamento que os livros didáticos têm dado ao processo de luta em prol da anistia.

Que a leitura desses artigos contribua para aprofundarmos a reflexão sobre os livros didáticos, sua produção e suas apropriações, pelos professores e pelos alunos.

\section{Referências}

CHOPPIN, Alan. História dos livros e das edições didáticas: sobre o estado da arte. Educação e Pesquisa. Revista da Faculdade de Educação da USP. São Paulo, v. 30, n. 3, p. 549-566, set./dez. 2004.

GATTI Jr., Décio. A escrita escolar da História - livro didático e ensino no Brasil (1970-1990). Bauru: Edusc, 2004.

MOREIRA, Maria Augusto; CORTEZ, Ana Sara Ribeiro Parente (Orgs.). Simpósio Nacional de História: História e Ética: Simpósios Temáticos e Resumos do XXV Simpósio Nacional de História ANPUH. Fortaleza, Ceará, 2009. p. 508. 


\section{Temática Especial \\ Livros Didáticos e Ensino de História}


